\title{
Isolation and characterisation of an extracellular alkaline protease of Aspergillus fumigatus
}

\author{
M. MONOD, G. TOGNI, L. RAHALISON and E. FRENK
}

Service de Dermatologie, Centre Hospitalier Universitaire Vaudois, 1011 Lausanne, Switzerland

\begin{abstract}
Summary. Aspergillus fumigatus secreted an inducible alkaline protease (AlPase) when cultivated in the presence of collagen $(200 \mu \mathrm{g} / \mathrm{ml})$ as sole nitrogen and carbon source. Proteolytic activity was maximum at $\mathrm{pH} 9.0$ with azocollagen as substrate. The enzyme, which was the major protein found in the supernate of a liquid culture, was purified by ammonium sulphate precipitation and gel filtration. The $M_{r}$ was determined to be $33 \mathrm{Kda}$ by gel filtration and sodium dodecyl sulphate-polyacrylamide gel electrophoresis. The isoelectric point was estimated to be $\mathrm{pH} 8 \cdot 2$. Divalent cations strongly inhibited enzyme activity, whereas non-ionic detergents and reducing agents had no effect. A. fumigatus AlPase was totally inhibited by phenylmethanesulphonyl fluoride, antipain, chymostatin and $\alpha$-2-macroglobulin. $A$. fumigatus AlPase is closely related to the A. oryzae AlPase, a serine protease of the subtilisin family, as attested by the antigen pattern seen by immunoblotting. The high collagenic activity and the ability of $A$. fumigatus AlPase to digest elastin could play a role in the invasion of the tissues by the fungus.
\end{abstract}

\section{Introduction}

Aspergillus fumigatus is a highly pathogenic fungus which causes broncho-pulmonary allergies, aspergillomas (fungus balls) and invasive aspergillosis. ${ }^{1}$ Reports of the incidence of invasive aspergillosis have increased in recent years, particularly in neutropenic patients. Consequently, interest in the pathogenic mechanisms of this fungus has increased.

Recent data suggest that the virulence of A. fumigatus is associated with the production of extracellular proteases. In mice, a correlation was established between elastase production by strains of $A$. fumigatus and the ability to cause invasive pulmonary aspergillosis. ${ }^{2}$ Elsewhere, it was shown that the proteolytic activity in the mouse brain increased in proportion to the growth of the fungus. ${ }^{3}$ Species of the genus Aspergillus produce many different extracellular enzymes. ${ }^{4}$ A $37-\mathrm{Kda}$ extracellular acid protease from A. fumigatus has been purified and characterised. ${ }^{5,6}$ In contrast, few data are available on neutral and alkaline exoproteases of this species. ${ }^{7,8} \mathrm{We}$ examined clinical strains of $\boldsymbol{A}$. fumigatus for production of an alkaline protease (AlPase) with a high collagenolytic activity and ability to digest elastin which could play a role in the invasion of lung tissue by the fungus, and compared the enzyme with the alkaline protease of A. oryzae, a species of Aspergillus used in the manufacturing process of fermented food in the Orient. ${ }^{4}$

\section{Materials and methods}

\section{Materials}

Malt agar was purchased from Oxoid (Basingstoke, Bucks) and soluble collagen from Serva (Heidelberg, Germany). Azocollagen, elastin-Congo red, casein, Trisma base (Tris), ammonium sulphate, Triton X100, Tween 80, 2-mercaptoethanol, 1, 4 dithiothreitol (DTT) and Freund's adjuvant, complete and incomplete, were from Sigma (St Louis, MS, USA). Polyacrylamide P60 gel, low-mol.-wt protein standards, and all reagents used for immunoblottingnitrocellulose membranes, gelatin, Tween 20, alkaline phosphatase-conjugated goat anti-rabbit IgG, nitroblue tetrozolium (NBT) and 5-bromo-4-chloro-3-indolyl phosphate (BCIP)-were from BioRad. DEAE Sephadex, ampholytes of $\mathrm{pH}$ range 3.5-9.5 and isoelectric focusing standards were from Pharmacia (Uppsala, Sweden). The protein inhibitors (4-amidinophenyl)-methanesulphonyl fluoride (APMSF), antipain di-hydrochloride, aprotinin, bestatin, L-1chloro-3-(4-tosylamido)-7-amino-2-heptanone hydrochloride (TLCK), L-1-chloro-3-(4-tosylamido)-4phenyl-2-butanone (TPCK), chymostatin, E 64, leupeptin, $\alpha$-2-macroglobulin, pepstatin, phenylmethylsulphonyl fluoride (PMSF), phosphoramidon and soybean trypsin inhibitor (SBTI) were obtained from Boehringer (Mannheim, Germany).

\section{Strains and growth conditions}

Ten strains of $A$. fumigatus were isolated from infected lung tissue and sputum of different patients 
at the Centre Hospitalier Universitaire Vaudois. The strains were maintained on malt agar slants at $4^{\circ} \mathrm{C}$. For inoculation, conidia from A. fumigatus were produced in bulk by growth on malt agar at $30^{\circ} \mathrm{C}$ for 5-10 days. For enzyme production, the strains were grown in liquid medium containing soluble collagen $0 \cdot 2 \%, \mathrm{w} / \mathrm{v}$ as sole nitrogen and carbon source. The medium was sterilised by autoclaving at $120^{\circ} \mathrm{C}$ for $15 \mathrm{~min}$. Flasks containing $500 \mathrm{ml}$ of medium were seeded with $c .10^{7}$ conidia and incubated at $30^{\circ} \mathrm{C}$ on an orbital shaker at $200 \mathrm{rpm}$ for $70 \mathrm{~h}$.

\section{Enzyme purification}

The culture supernate was separated from the mycelium by filtration through paper tissue. Ammonium sulphate was dissolved at room temperature in the supernate to $90 \%$ saturation. From this point, all steps of enzyme purification were done at $4^{\circ} \mathrm{C}$. The precipitated proteins were collected by centrifugation and resuspended in 1/150th of the original volume of distilled water. Insoluble material was removed by centrifugation at $5000 \mathrm{~g}$ for $5 \mathrm{~min}$, and the supernate was dialysed against $20 \mathrm{~mm}$ Tris- $\mathrm{HCl}, \mathrm{pH} 8 \cdot 0$, for $4 \mathrm{~h}$. After reduction of the volume to $5 \mathrm{ml}$ by ultrafiltration, (Ultracent-30 system, BioRad), the enzyme solution was chromatographed on a column of polyacrylamide $\mathrm{P} 60 \mathrm{gel}$ in $20 \mathrm{~mm}$ Tris-HCl buffer, $\mathrm{pH} 8 \cdot 0$.

\section{Purification of A. oryzae protease}

Crude powder $(10 \mathrm{mg})$ of commercially available A. oryzae AlPase was resuspended in $5 \mathrm{ml}$ of $20 \mathrm{mM}$ Tris- $\mathrm{HCl}$, $\mathrm{pH} 7.0$, with $0.5 \mathrm{ml}$ of DEAE Sephadex (Pharmacia) pre-swollen in the same buffer. After sedimentation of the gel, the supernate was chromatographed through a polyacrylamide $\mathrm{P} 60$ gel column as described for $\boldsymbol{A}$. fumigatus AlPase.

\section{Protein concentration}

Protein concentrations were measured by the method of Bradford ${ }^{9}$ with a BioRad dye reagent (no. 500-0006) and casein as protein standard.

\section{Proteolytic assays}

The AlPase activity was measured on azocollagen at different $\mathrm{pH}$ values in citrate buffer $(50 \mathrm{mM}, \mathrm{pH} 4$ 7), in Tris-HCl buffer ( $50 \mathrm{mM}, \mathrm{pH}$ 6-10) and in glycine$\mathrm{NaOH}$ buffer (100 mM, pH 8-12). Activities measured at the same $\mathrm{pH}$ with different buffers were identical. From a suitably diluted protease solution in buffer at $30^{\circ} \mathrm{C}, 1 \mathrm{ml}$ was added to $10 \mathrm{mg}$ of substrate. After incubation for $10 \mathrm{~min}$ with continuous shaking at $30^{\circ} \mathrm{C}$, the reaction was stopped by removing the insoluble collagen by centrifugation. The absorbance at $520 \mathrm{~nm}$ of the coloured supernate was measured. After digestion, $1 \mathrm{mg}$ of substrate gave an absorbance value of 0.60 . For practical purposes, one unit of enzyme activity was defined as that producing an

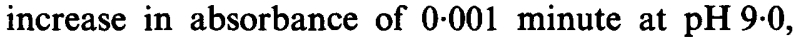
which corresponded to the digestion of $1.65 \mu \mathrm{g}$ of azocollagen.

Activity against elastin was measured with elastin Congo red as substrate at a concentration of $10 \mathrm{mg} / \mathrm{ml}$ in $50 \mathrm{~mm}$ Tris- $\mathrm{HCl}, \mathrm{pH}$ 6-10. The reaction was stopped by centrifugation. The absorbance of the orange supernate was measured at $495 \mathrm{~nm} ; 1 \mathrm{mg}$ of substrate, when digested, gave an absorbance value of 0.42.

Activity against heat-denaturated casein was measured at a concentration of $5 \mathrm{mg} / \mathrm{ml}$ in $50 \mathrm{mM}$ Tris$\mathrm{HCl}, \mathrm{pH}$ 6-10. After precipitation by trichloroacetic acid (4\% final concentration) and centrifugation, soluble peptides remaining in the supernate were measured by the method of Lowry et al. $;^{10} 1 \mathrm{mg}$ of substrate, when digested, gave an absorbance value of $1 \cdot 71$.

\section{Heat stability}

A. fumigatus AlPase, $1 \mu \mathrm{g}$ in $1 \mathrm{ml}$ of $50 \mathrm{mM}$ Tris$\mathrm{HCl}$ buffer ( $\mathrm{pH} \mathrm{9),} \mathrm{was} \mathrm{pre-incubated} \mathrm{in} \mathrm{a} \mathrm{sealed} \mathrm{tube}$ for 10 min at $4,30,40,50,60$ and $80^{\circ} \mathrm{C}$ before the assay. Enzymic activity was measured as described above after adding the mixture to $10 \mathrm{mg}$ of azocollagen.

\section{Effect of detergents, organic solvent, reducing agents and divalent cations}

The actions of detergents [sodium dodecyl sulphate (SDS), Triton $\times 100$ and Tween 80] as well as organic solvents [dimethyl sulphoxide (DMSO) and ethanol], reducing agents (2-mercaptoethanol and DTT) and divalent cations on A. fumigatus AlPase were tested. The enzyme, $1 \mu \mathrm{g}$ in $1 \mathrm{ml}$ of $50 \mathrm{~mm}$ Tris- $\mathrm{HCl}$ buffer (pH 9), was pre-incubated with each reagent or the divalent cations for $10 \mathrm{~min}$ at $30^{\circ} \mathrm{C}$. Enzymic activity was assayed as described above by adding the enzyme mixture to $10 \mu \mathrm{g}$ of azocollagen. For each cation assay, an appropriate blank containing buffer, substrate and cation was treated identically. Absorbance of digested azocollagen in the enzymic assay was measured against the corresponding blank. An appropriate control containing enzyme and substrate only was assayed simultaneously.

\section{Effects of proteinase inhibitors}

The inhibitors APMSF, iodoacetamide, EDTA, antipain, leupeptin, chymostatin, phosphoramidon, E64, SBTI, $\alpha$-2-macroglobulin and aprotinin were dissolved in water and PMSF, pepstatin, TLCK and TPCK were dissolved in ethanol. Either 10 or $50 \mu \mathrm{g}$ of inhibitor was added to $1 \mu \mathrm{g}$ of enzyme in $1 \mathrm{ml}$ of $2 \mathrm{mM}$ Tris- $\mathrm{HCl}$ buffer, $\mathrm{pH} 6 \cdot 5$. The mixture was incubated for $20 \mathrm{~min}$ at $30^{\circ} \mathrm{C}$ and assays were performed after adding the mixture to $10 \mathrm{mg}$ of azocollagen with $50 \mu \mathrm{l}$ of $1 \mathrm{M}$ Tris- $\mathrm{HCl}, \mathrm{pH} 9$. Preincubation in the presence of inhibitor was done at 
$\mathrm{pH} 6.5$ because some inhibitors were unstable at $\mathrm{pH}$ $>7 \cdot 5$. An appropriate control without inhibitor was assayed simultaneously.

\section{Electrophoresis}

Protein extracts were analysed by sodium dodecyl sulphate-polyacrylamide gel electrophoresis (SDSPAGE) according to the method of Laemmli ${ }^{11}$ with a separation gel of polyacrylamide $9 \%$.

\section{Iso-electric points}

The iso-electric point was determined with a Multiphor II electrophoresis system (Pharmacia). The horizontal, non-denaturating gel contained polyacrylamide $4 \%$, glycerol $15 \%$ and ampholytes $2.4 \%$ in the $\mathrm{pH}$ range $3 \cdot 5-9 \cdot 5$. After loading the protein samples, the gel was subjected to $1 \mathrm{w} / \mathrm{cm}$ of gel length during $50 \mathrm{~min}$ at $4^{\circ} \mathrm{C}$ in an atmosphere of $\mathrm{N}_{2}$. The iso-electric point of the purified proteins was determined by comigration with iso-electric focusing standards (pH 3.5-9.3).

\section{Preparation of anti-AlPase immune sera}

New Zealand White rabbits were given $300 \mu \mathrm{g}$ of purified AlPase in $0.5 \mathrm{ml}$ of phosphate-buffered saline (PBS) emulsified with an equal volume of Freund's complete adjuvant by intradermal injection in the back. After 3 weeks, a booster dose of $30 \mu \mathrm{g}$ of AlPase emulsified in Freund's incomplete adjuvant was given to increase the anti-AlPase titres. Sera were separated from the clotted blood samples.

\section{Immunoblotting}

The proteins were transferred passively on to a nitrocellulose membrane by pressing $\left(1 \mathrm{lb} / 100 \mathrm{~cm}^{2}\right)$ the gel between two membranes of nitrocellulose overnight in PBS buffer. About $50 \%$ of the total proteins were transferred on to each of the membranes. Protein binding sites were blocked by incubation in gelatin $3 \%$ in Tris-buffered saline solution (TBS; $20 \mathrm{~mm}$ Tris, $500 \mathrm{~mm} \mathrm{NaCl}, \mathrm{pH} \mathrm{7 \cdot 5)}$ at $22^{\circ} \mathrm{C}$ during $1 \mathrm{~h}$. The nitrocellulose membrane was then washed with gentle agitation in TTBS (TBS + Tween $200.05 \%$ ), and subsequently incubated overnight with gentle agitation at $22^{\circ} \mathrm{C}$ with the rabbit immune antiserum diluted 1 in 1000 in TTBS. After washing twice in TTBS, the nitrocellulose membrane was incubated for $2 \mathrm{~h}$ at $22^{\circ} \mathrm{C}$ with alkaline phosphatase-conjugated goat anti-rabbit IgG at a 1 in 3000 dilution in TTBS. After washing twice with TTBS and once with TBS, the membrane was incubated for $5 \mathrm{~min}$ at $22^{\circ} \mathrm{C}$ in $50 \mathrm{ml}$ of alkaline phosphatase buffer $(100 \mathrm{nM}$ Tris- $\mathrm{HCl}$, pH 9.5, $100 \mathrm{mM} \mathrm{NaCl}, 5 \mathrm{mM} \mathrm{MgCl}_{2}$ ) containing a mixture of $200 \mu \mathrm{l}$ of NBT $(75 \mathrm{mg} / \mathrm{ml}$ in $70 \% \mathrm{~N}$. Ndimethylformamide) and $150 \mu \mathrm{l}$ of BCIP $(50 \mathrm{mg} / \mathrm{ml}$ in $100 \% \mathrm{~N}$. N-dimethylformamide). The reaction was stopped by washing the membrane in water.

\section{Results}

\section{Purification and properties of A. fumigatus alkaline protease}

All 10 strains of $A$. fumigatus examined showed comparable proteolytic activities in collagen medium. For all strains, proteolytic activity was maximum at pH 9.0 with azocollagen as substrate. After growth for $72 \mathrm{~h}$ the concentration of protein in the supernate had fallen from $200 \mu \mathrm{g} / \mathrm{ml}$ to $6 \mu \mathrm{g} / \mathrm{ml}$. No activity was detected when the fungus was grown in Sabouraud liquid medium.

Protease purification and characterisation was performed mainly with one strain (CHUV 192-88). The purification steps and yields of a typical experiment are summarised in table I. A single peak of proteolytic activity was obtained after P 60 gel chromatography. This peak corresponded to the major peak of protein eluted from the gel column. The purified enzyme migrated as a major protein band in SDS-PAGE (fig. 1, track 1). The estimated $M_{r}$ of the enzyme of $33 \mathrm{Kda}$ corresponded to the $M_{r}$ of the protease obtained by $\mathrm{P} 60$ gel chromatography. The enzyme was the major protein secreted by the fungus as shown by the protein profile of the $90 \%$ saturated ammonium sulphate precipitate of the culture supernate (fig. 1, track 3). In view of this, the overall enrichment expected after purification could be only small (table I). Although ion exchange chromatography was not necessary for its purification, $A$. fumigatus AlPase could be bound at $\mathrm{pH}$ 8.7 to QUAE Sephadex

Table I. Purification of the extracellular alkaline protease of $\boldsymbol{A}$. fumigatus

\begin{tabular}{|c|c|c|c|c|c|c|}
\hline Purification step & $\begin{array}{l}\text { Total } \\
\text { volume } \\
\text { (ml) }\end{array}$ & $\begin{array}{c}\text { Total } \\
\text { protein } \\
(\mu \mathrm{g})\end{array}$ & $\begin{array}{l}\text { Total } \\
\text { enzyme } \\
\text { activity } \\
\text { (units) }\end{array}$ & $\begin{array}{c}\text { Yield } \\
(\%)\end{array}$ & $\begin{array}{c}\text { Specific } \\
\text { activity } \\
\text { (units } / \mu \mathrm{g} \text { ) }\end{array}$ & Purification \\
\hline Culture supernate & 1000 & 6600 & $98.4 \times 10^{3}$ & 100 & 14.9 & $1 \cdot 0$ \\
\hline Ammonium sulphate precipitation & 6 & 1728 & $59.3 \times 10^{3}$ & $60 \cdot 2$ & $34 \cdot 3$ & $2 \cdot 3$ \\
\hline P60 gel filtration & 14 & 526 & $42.6 \times 10^{3}$ & $43 \cdot 1$ & $80 \cdot 7$ & $5 \cdot 4$ \\
\hline
\end{tabular}



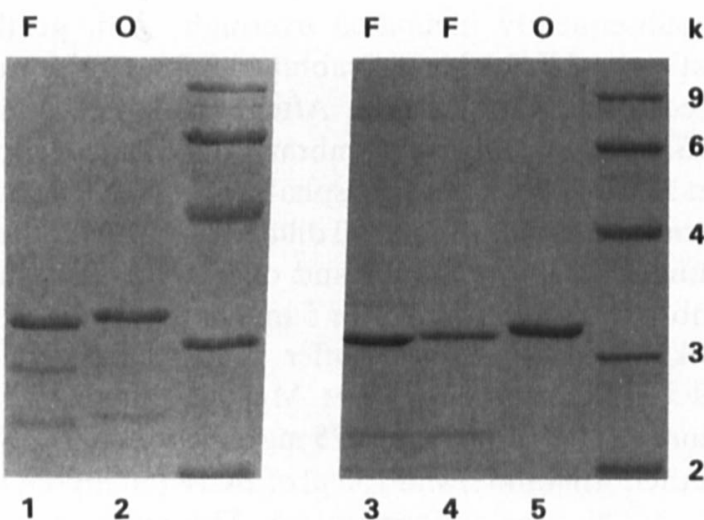

kDa

97.4

66.2

42.6

Fig. 1. SDS-PAGE ( $9 \%$ gels) of AlPase preparations ( $2.5 \mu \mathrm{g})$ of $A$. fumigatus (track F) and A. oryzae (track $\mathbf{O}$ ) stained with Coomassie Brilliant Blue R-250. $\mathrm{M}_{\mathrm{r}}$ markers: phosphorylase B, $97.4 \mathrm{Kda}$; bovine serum albumin, $66.2 \mathrm{Kda}$; ovalbumin, $42.6 \mathrm{Kda}$; bovine carbonic anhydrase, $31.0 \mathrm{Kda}$; soybean trypsin inhibitor, $21.5 \mathrm{Kda}$. Tracks 1, 2, 4 and 5: purified $A$. fumigatus and $A$. oryzae AlPases; 3: protein profile of the $90 \%$ saturated ammonium sulphate of the culture supernate. In tracks 3,4 and 5 all steps of preparation of the samples were done in the presence of PMSF $50 \mu \mathrm{g} / \mathrm{ml}$.

(Pharmacia) equilibrated with $50 \mathrm{~mm}$ Tris $\mathrm{HCl}$, and eluted with $50 \mathrm{~mm}$ Tris HCL, $\mathrm{pH} 8 \cdot 3$. These values are consistent with the iso-electric point estimated to be $\mathrm{pH} 8.2$ by iso-electric focusing.

The purified AlPase was stable for at least 2 weeks at $4^{\circ} \mathrm{C}$ and for 6 months at $-20^{\circ} \mathrm{C}$ in $50 \mathrm{mM}$ Tris- $\mathrm{HCl}$ buffer. A 10 -min pre-treatment at $60^{\circ} \mathrm{C}$ inactivated the enzyme whereas the same treatment at $50^{\circ} \mathrm{C}$ had no effect. The enzyme showed a marked peak of activity at $\mathrm{pH} 9.0$ and was inactive below $\mathrm{pH} 5.0$ and above $\mathrm{pH} 11 \cdot 0$ (fig. 2). Interestingly, appreciable activity was observable on elastin-Congo red, whereas this substrate was completely resistant to trypsin (table II).

Non-ionic detergents such as Triton $\times 100$ and Tween 80 at a concentration of $1 \%$ had no effect on AlPase activity. SDS at a concentration of $0.1 \%$ had no effect, but a decrease in activity of $60 \%$ was observed at a concentration of $1 \%$. Neither was any effect on AlPase activity observed in the presence of organic solvents such as DMSO and ethanol, nor with

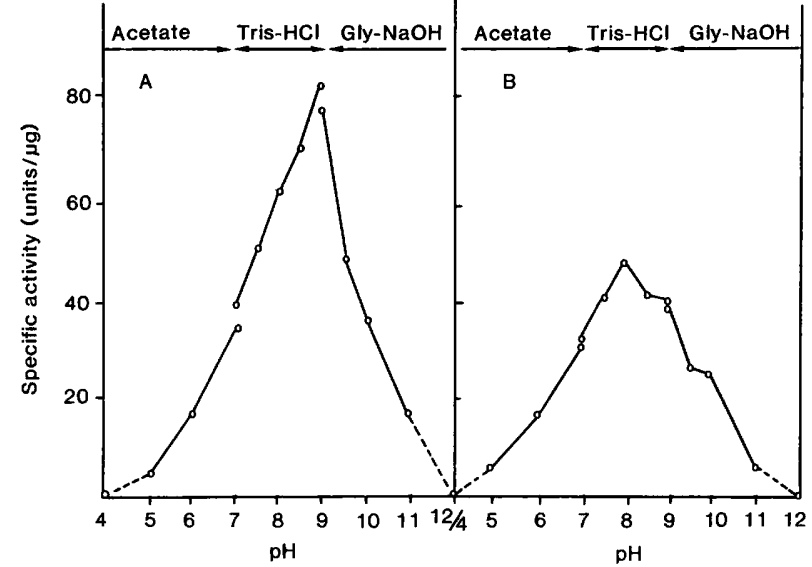

Fig. 2. Effect of $\mathrm{pH}$ on specific activity of A. fumigatus (A) and A. oryzae (B) AlPases, with azocollagen as substrate.

reducing agents such as 2-mercaptoethanol and DTT (table III).

A. fumigatus AlPase was very sensitive to divalent cations. Reduced activity was observed in presence of $1 \mathrm{mM}$ of the eight cations tested. Concentrations of $10 \mathrm{mM}$ of $\mathrm{Mg}^{++}, \mathrm{Cu}^{++}$or $\mathrm{Ca}^{++}$caused inhibitions of 53,60 and $68 \%$ respectively, whereas the enzyme was completely inactivated by $10 \mathrm{mM} \mathrm{Mn}{ }^{++}, \mathrm{Zn}^{++}$, $\mathrm{Co}^{++}, \mathrm{Pb}^{++}$or $\mathrm{Hg}^{++}$. In contrast, a $10 \mathrm{~mm}$ concentration of monovalent cations such as $\mathrm{Na}^{+}$or $\mathrm{K}^{+}$had no effect on AlPase activity.

Different protease inhibitors were tested on A. fumigatus AlPase activity. The enzyme was totally inactivated by PMSF, antipain and chymostatin $10 \mu \mathrm{g} / \mathrm{ml}$, and by $\alpha-2-\mathrm{macroglobulin} 50 \mu \mathrm{g} / \mathrm{ml}$. Leupeptin inhibited the enzymatic activity by $43-52 \%$ at a concentration of $10-50 \mu \mathrm{g} / \mathrm{ml}$. The enzyme was not inhibited by APMSF, iodoacetamide, EDTA, pepstatin, phosphoramidon, E64, SBTI, aprotinin, TLCK or TPCK (table III).

The proteins in the culture supernates of the nine other strains of $A$. fumigatus were concentrated by $90 \%$ ammonium sulphate. The nine strains secreted a protein of identical $\mathrm{M}_{\mathrm{r}}(33 \mathrm{Kda})$ that co-migrated on SDS-PAGE with the purified AlPase of strain CHUV 192-88.

Table II. Activities of $\boldsymbol{A}$. fumigatus and A. oryzae AlPases and trypsin on different substrates at $\mathrm{pH} 7.4$ and respective $\mathrm{pH}$ optima

\begin{tabular}{|c|c|c|c|c|c|}
\hline \multirow{3}{*}{ Substrate } & \multicolumn{5}{|c|}{ Enzyme activity* of } \\
\hline & \multicolumn{2}{|c|}{ A. fumigatus AlPase } & \multicolumn{2}{|c|}{ A. oryzae AlPase } & \multirow{2}{*}{$\frac{\text { Trypsin }}{\underset{7.4}{\text { pH optimum }}}$} \\
\hline & $\mathrm{pH} 7 \cdot 4$ & $\begin{array}{c}\text { pH optimum } \\
9.0\end{array}$ & $\mathrm{pH} 7.4$ & $\underset{8 \cdot 0}{\mathrm{pH} \text { optimum }}$ & \\
\hline Azocollagen & $5 \cdot 01$ & 8.80 & 4.04 & $4 \cdot 75$ & $7 \cdot 58$ \\
\hline Elastin congo red & 0.073 & $0 \cdot 130$ & 0.026 & 0.057 & ND \\
\hline Casein & $1 \cdot 17$ & $1 \cdot 21$ & $1 \cdot 30$ & 1.41 & 0.43 \\
\hline
\end{tabular}

ND, not detected.

* Amount of substrate (mg) digested by $1 \mu \mathrm{g}$ of enzyme at $30^{\circ} \mathrm{C}$ in $1 \mathrm{~h}$. 
Table III. Summary of properties of $A$. fumigatus AlPase

\begin{tabular}{|c|c|c|}
\hline Molecular weight & & 33000 \\
\hline pH optimum & & $9 \cdot 0$ \\
\hline Iso-electric point & & $8 \cdot 2$ \\
\hline Heat stability & & $50^{\circ} \mathrm{C}$ for $10 \mathrm{~min}$ \\
\hline $\begin{array}{l}\text { Effects of detergents an } \\
\text { SDS } \\
\text { Tween } 80 \\
\text { Triton } \times 100 \\
\text { Ethanol } \\
\text { DMSO }\end{array}$ & $\begin{array}{l}\text { ganic solvents } \\
0 \cdot 1-1 \cdot 0 \% \\
0 \cdot 1-1 \cdot 0 \% \\
0 \cdot 1-1 \cdot 0 \% \\
1 \cdot 0-5 \cdot 0 \% \\
1 \cdot 0-5 \cdot 0 \%\end{array}$ & $\begin{array}{l}0-60 \% \text { inhibition } \\
\text { no effect } \\
\text { no effect } \\
\text { no effect } \\
\text { no effect }\end{array}$ \\
\hline $\begin{array}{l}\text { Effect of reducing agen } \\
\text { 2-mercaptoethanol } \\
\text { DTT }\end{array}$ & $\begin{array}{l}0 \cdot 1-1 \cdot 0 \% \\
0 \cdot 1-1 \cdot 0 \%\end{array}$ & $\begin{array}{l}\text { no effect } \\
\text { no effect }\end{array}$ \\
\hline $\begin{array}{l}\text { Effect of divalent metal } \\
\mathrm{Mg} \\
\mathrm{Cu} \\
\mathrm{Ca} \\
\mathrm{Mn} \\
\mathrm{Zn} \\
\mathrm{Co} \\
\mathrm{Pb} \\
\mathrm{Hg}\end{array}$ & $\begin{array}{l}\text { oride } \\
1-10 \mathrm{mM} \\
1-10 \mathrm{mM} \\
1-10 \mathrm{mM} \\
1-10 \mathrm{mM} \\
1-10 \mathrm{mM} \\
1-10 \mathrm{mM} \\
1-10 \mathrm{mM} \\
1-10 \mathrm{mM}\end{array}$ & $\begin{array}{l}15-53 \% \text { inhibition } \\
17-68 \% \text { inhibition } \\
27-60 \% \text { inhibition } \\
21-100 \% \text { inhibition } \\
37-100 \% \text { inhibition } \\
72-100 \% \text { inhibition } \\
75-100 \% \text { inhibition } \\
94-100 \% \text { inhibition }\end{array}$ \\
\hline $\begin{array}{l}\text { Effect of inhibitors } \\
\text { Class specific } \\
\text { PMSF } \\
\text { APMSF } \\
\text { Iodoacetamide } \\
\text { EDTA }\end{array}$ & $\begin{array}{l}10-50 \mu \mathrm{g} / \mathrm{ml} \\
10-50 \mu \mathrm{g} / \mathrm{ml} \\
10-50 \mu \mathrm{g} / \mathrm{ml} \\
10-50 \mathrm{mM}\end{array}$ & $\begin{array}{l}100 \% \text { inhibition } \\
\text { no effect } \\
\text { no effect } \\
\text { no effect }\end{array}$ \\
\hline $\begin{array}{l}\text { Microbial origin } \\
\text { antipain } \\
\text { leupeptin } \\
\text { chymostatin } \\
\text { pepstatin } \\
\text { phosphoramidon } \\
\text { E } 64\end{array}$ & $\begin{array}{l}10-50 \mu \mathrm{g} / \mathrm{ml} \\
10-50 \mu \mathrm{g} / \mathrm{ml} \\
10-50 \mu \mathrm{g} / \mathrm{ml} \\
10-50 \mu \mathrm{g} / \mathrm{ml} \\
10-50 \mu \mathrm{g} / \mathrm{ml} \\
1 \mathrm{mg} / \mathrm{ml}\end{array}$ & $\begin{array}{l}100 \% \text { inhibition } \\
43-52 \% \text { inhibition } \\
100 \% \text { inhibition } \\
\text { no effect } \\
\text { no effect } \\
\text { no effect }\end{array}$ \\
\hline $\begin{array}{l}\text { High molecular weigl } \\
\text { SBTI } \\
\alpha 2 \text {-macroglobulin } \\
\text { aprotinin }\end{array}$ & $\begin{array}{l}10-50 \mu \mathrm{g} / \mathrm{ml} \\
10-50 \mu \mathrm{g} / \mathrm{ml} \\
10-50 \mu \mathrm{g} / \mathrm{ml}\end{array}$ & $\begin{array}{l}\text { no effect } \\
59-100 \% \text { inhibition } \\
\text { no effect }\end{array}$ \\
\hline $\begin{array}{l}\text { Others } \\
\text { TLCK } \\
\text { TPCK }\end{array}$ & $\begin{array}{l}10-50 \mu \mathrm{g} / \mathrm{ml} \\
10-50 \mu \mathrm{g} / \mathrm{ml}\end{array}$ & $\begin{array}{l}\text { no effect } \\
\text { no effect }\end{array}$ \\
\hline
\end{tabular}

\section{Relatedness of $A$. fumigatus and $A$. oryzae AlPases}

Extracellular alkaline proteases are produced by species of the flavus-oryzae group of Aspergillus. We compared the $A$. fumigatus AlPase with the $A$. oryzae AlPase commonly used in the manufacturing process of fermented food. Commercially available $A$. oryzae AlPase was purified as described. The $\mathrm{M}_{\mathrm{r}}$ of the protein was $34 \mathrm{Kda}$, barely $1 \mathrm{Kda}$ higher than the $\mathrm{M}_{\mathrm{r}}$ of $A$. fumigatus protease on a SDS-PAGE gel (fig. 1, tracks 1 and 2) which corresponds to that reported by Tatsumi et al. ${ }^{12}$ A. oryzae AlPase differed from A. fumigatus AlPase in having a much lower isoelectric point (pH 6.5) and a lower optimum $\mathrm{pH}$ for azocollagen digestion (fig. 2). Both enzymes digested casein with about the same efficiency, but, interestingly, the specific activity of $A$. oryzae protease against collagen or elastin was twofold lower than that of A. fumigatus at their respective optimal $\mathrm{pH}$ values (table II). Like $A$. fumigatus AlPase, $A$. oryzae AlPase was inhibited by PMSF, antipain and chymostatin, but not by APMSF, iodoacetamide, EDTA, pepstatin, phosphoramidon, E64, SBTI, aprotinin, TLCK or TPCK. On the other hand, a concentration of $\alpha-2$ macroglobulin of $50 \mu \mathrm{g} / \mathrm{ml}$, which totally inhibited A. fumigatus AlPase, caused only $12 \%$ inhibition of A. oryzae AlPase.

Immunoblotting was performed with an equal amount $(50 \mathrm{ng})$ of each enzyme transferred on to nitrocellulose membranes. Both proteins were detected with the same intensity by $A$. fumigatus AlPase antiserum. However, A. oryzae AlPase antiserum reacted more weakly with the heterologous protein (fig. 3).

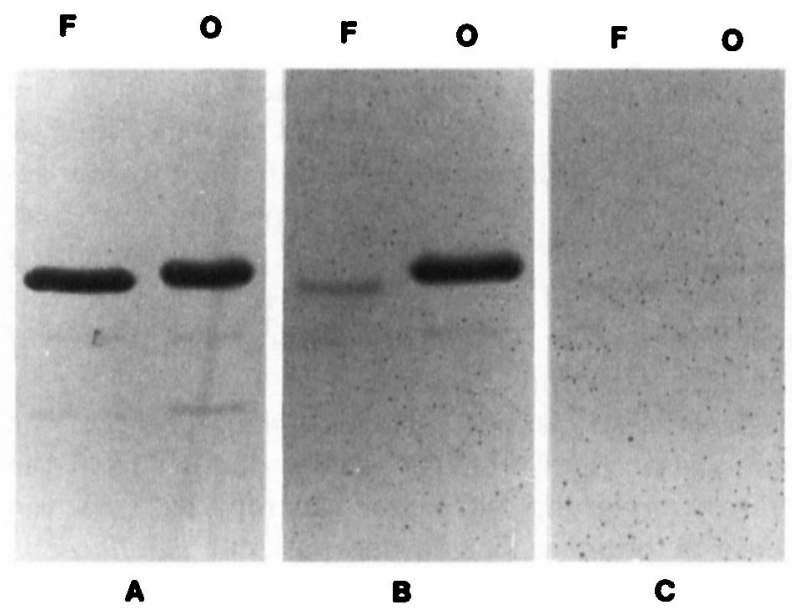

Fig. 3. Cross-reactions of $A$. fumigatus $(\mathbf{F})$ and $A$. oryzae $(\mathbf{O})$ AlPases with $A$. fumigatus and $A$. oryzae AlPase antisera; $50 \mathrm{ng}$ of protein was transferred on to nitrocellulose membranes and blots were treated with antisera against $A$. fumigatus AlPase (A), A. oryzae AlPase (B) and serum from non-immunised rabbits (C). The proteins were detected with alkaline-phosphatase-conjugated goat antirabbit IgG.

\section{Discussion}

When cultured in soluble collagen as the sole carbon and nitrogen source, $\boldsymbol{A}$. fumigatus secreted a protease to provide nutrients necessary for growth. The enzyme was apparently the major protein secreted by the fungus (fig. 1, track 3). Preparations of the purified A. fumigatus and A. oryzae AlPases showed two minor bands of 24 and 29,25 and $30 \mathrm{Kda}$ respectively on SDS-PAGE (fig. 1, tracks 1 and 2). Further gel filtration and ion exchange chromatography (not shown) did not result in preparations showing a unique major band. Since the two minor bands could be eliminated in the preparation from $A$. oryzae by preincubation of the enzyme with PMSF, these apparently homologous minor bands are interpreted as being self degradation products of the enzyme. With the same inhibitor, the second band was still present in a preparation of A. fumigatus AlPase (fig. 1, tracks 4 and 5.).

Immunoblotting showed that $A$. fumigatus and $A$. oryzae AlPases are closely related, suggesting the existence of common and specific domains in the 
enzymes secreted by the two species. However, A. fumigatus AlPase differed in having a much higher iso-electric point and a marked peak of activity at pH 9. The A. fumigatus AlPase presented a broad spectrum with appreciable activity, and at a physiological $\mathrm{pH}$ value of $\mathbf{7 \cdot 4}$, the enzyme still had a higher specific activity on collagen and elastin than $A$. oryzae AlPase. The amino acid sequence of $A$. oryzae AlPase shows homology with other serine proteases of the subtilisin family, e.g., Saccharomyces cerevisiae protease B, Yarrowia lipolytica alkaline extracellular protease, Tritirachium album proteinase $\mathrm{K}$ and Bacillus amyloliquefaciens subtilisin. ${ }^{12}$ Enzymes of the subtilisin family are totally inactivated by PMSF whereas TLCK and TPCK, inhibitors of trypsin and chymotrypsin respectively, have no effect. ${ }^{13-16}$ As shown in particular for $S$. cerevisiae proteinase $B,{ }^{13}$ the $A$. fumigatus and $A$. oryzae AlPases were inhibited by PMSF, chymostatin and antipain, but not by iodoacetamide, EDTA, pepstatin, phosphoramidon, E64, SBTI, aprotinin, TLCK and TPCK. Immunoblotting and the effects of various protease inhibitors support the view that the A.fumigatus AlPase is a protease of the subtilisin family.

A. oryzae is classified in the "flavus" group of the genus Aspergillus which is clearly distinct from the "fumigatus" group. ${ }^{4} A$. oryzae was reported to be the cause of brain lesions in one patient. ${ }^{17}$ A. flavus is

\section{References}

1. Vanden Bossche H, Mackenzie DWR, Cauwenbergh G (eds) Aspergillus and aspergillosis. New York, Plenum Press. 1988.

2. Kothary MH, Chase T, MacMillan JD. Correlation of elastase production by some strains of Aspergillus fumigatus with ability to cause pulmonary invasive aspergillosis in mice. Infect Immun 1984; 43: 320-325.

3. Miyaji M, Nishimura K. Relationship between proteolytic activity of Aspergillus fumigatus and the fungus invasiveness of mouse brain. Mycopathologia 1977; 62: 161-166.

4. Raper KB, Fennell DI. The genus Aspergillus. Baltimore, Williams and Wilkins Co. 1965.

5. Panneerselvam M, Dhar SC. Chromatographic purification and homogeneity of extracellular acid proteinase of Aspergillus fumigatus. Ital J Biochem 1980; 29: 102-112.

6. Panneerselvam M, Dhar SC. Physico-chemical properties of the acid proteinase from $A$. fumigatus. Ital J Biochem 1981; 30: 63-74.

7. Jönsson AG, Martin SM. Protease production by Aspergillus fumigatus. Agric Biol Chem 1964; 28: 734-739.

8. Martin SM, Jönsson AG. An extracellular protease from Aspergillus fumigatus. Can J Biochem 1965; 43: 1745-1753.

9. Bradford MM. A rapid and sensitive method for the quantitation of microgram quantities of protein utilizing the principle of protein-dye binding. Anal Biochem 1976; 72 : 248-254.

10. Lowry OH, Rosebrough NJ, Farr AL, Randall RJ. Protein measurement with the Folin phenol reagent. J Biol Chem 1951; 193: 265-275. recognised as causing invasive aspergillosis, but with a frequency which does not approach that of A. fumigatus. Like A. oryzae, A. flavus secretes an AlPase. ${ }^{18}$ The high collagenolytic activity and the ability of AlPases to digest elastin can explain the ability of Aspergillus spp. to invade and destroy the host tissues. In this sense it has already been shown that all isolates of $A$. fumigatus and $A$. flavus causing aspergillosis produced elastase, but not all isolates producing elastase were associated with invasive disease.$^{19}$ Other correlations between protease activity and ability to cause invasive aspergillosis in animals tends to support the view that the pathogenicity of A. fumigatus is related to its protease activity. ${ }^{2,3,20}$ However, to establish the role of the isolated protease in the virulent behaviour of the fungus, synthesis of this protease must be demonstrated in the infected host and inactivation of the enzyme by gene disruption must be shown to result in reduced pathogenicity.

We thank Dr J. Bille for providing some $A$. fumigatus strains, Dr E. Bannerman for preparing the antisera, P. Lemarchand for preparing IEF, Dr $\mathbf{H}$. Pooley for editorial assistance, and $\mathbf{J}$. Chevalley for her secretarial assistance.

Addendum in proof. Isolation of $\boldsymbol{A}$. fumigatus AlPase was published by Reichard et al. ( $J$ Med Microbiol, 1990; 33: 243-251) when this paper was in press.
11. Laemmli UK. Cleavage of structural proteins during the assembly of the head of bacteriophage T4. Nature 1970 ; 227: 680-685.

12. Tatsumi H, Ogawa $Y$, Murakami $S$ et al. A full length cDNA clone for the alkaline protease from Aspergillus oryzae: structural analysis and expression in Saccharomyces cerevisiae. Mol Gen Genet 1989; 219: 33-38.

13. Kominami E, Hoffschulte $H$, Holzer $H$. Purification and properties of proteinase B from yeast. Biochim Biophys Acta $1981 ; 661$ : 124-135.

14. Ogrydziak DM, Scharf SJ. Alkaline extracellular protease produced by Saccharomycopsis lipolytica CX 161-1B. J Gen Microbiol 1982; 128 : 1225-1234.

15. Ebeling W, Hennrich N, Klockow M, Metz H, Orth HD, Lang H. Proteinase $\mathrm{K}$ from Tritirachium album limber. Eur J Biochem 1974; 47: 91-97.

16. Ottesen M, Svendsen I. The subtilisins. Methods Enzymol 1970; 19: 199-215.

17. Ziskind J, Pizzolato P, Buff EE. Aspergillosis of the brain. Report of a case. Am J Clin Pathol 1958; 29 : 554-559.

18. Nakagawa Y. Alkaline proteinases from Aspergillus. Methods Enzymol 1970; 19: 581-591.

19. Rhodes JC, Bode RB, McCuan-Kirsch CM. Elastase production in clinical isolates of Aspergillus. Diagn Microbiol Infect Dis 1988 ; 10 : 165-170.

20. Staib F. Pleural fluid as nutrient substratum for Aspergillus fumigatus and $A$. flavus: submerged growth in pleural fluid and extracellular proteolysis in pleural fluid agar. Zentralb Bakteriol Mikrobiol Hyg A 1985; 260 : 543-549. 